\title{
Kinetochore Protein Nuf2
}

National Cancer Institute

\section{Source}

National Cancer Institute. Kinetochore Protein Nuf2. NCI Thesaurus. Code C114816.

Kinetochore protein Nuf2 (464 aa, $54 \mathrm{kDa}$ ) is encoded by the human NUF2 gene. This protein is involved in mitosis. 